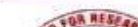 SPCRD GLOBAL PUBLISHING \\ Sustainable Solutions Review of Applied Management and Social Sciences \\ Journal homepage: http://ramss.spcrd.org

\section{Examining Effectuation Theory: Lessons for Entrepreneurial Activity in Developing Countries}

\author{
${ }^{a}$ Muhammad Mansoor Ali, ${ }^{b}$ Mahnaz Muhammad Ali, ${ }^{c}$ Lubna Shahnaz Umer \\ a Assistant Professor, Economics Department, NUML, Islamabad, Pakistan \\ Email:mmali@numl.edu.pk \\ ${ }^{\mathrm{b}}$ Assistant Professor, Islamia University, Bahawalpur, Pakistan \\ Email: mahnaz.ali@iub.edu.pk \\ ${ }^{\mathrm{c}}$ Economist, Policy Research Innovation, Development and Education (PRIDE), Pakistan \\ Email: Shahnazlubna9@gmail.com
}

\begin{abstract}
ARTICLE DETAILS
History:

Accepted 25 May 2021

Available Online June 2021

Keywords:

Globalization; Entrepreneurship;

Effectuation Theory

JEL Classification:

$\mathrm{Fo}$, L26,

DOI: $10.47067 /$ ramss.v4i2.159

ABSTRACT

Business development and utilization of indigenous resources is directly linked with the level of economic growth of any society. Globalization and innovation have made it challenging for developing countries to keep pace of business development to attain sustainable levels of economic growth. Developing counties are faced with the problems of nonconducive external business environment, complex business registration and taxation systems, scarcity of finance, technological support and logistics, and lack of managerial skills and financial advice. Enhancing entrepreneurial effectuation can enable the entrepreneurs of developing countries to successfully create such businesses that are not only efficient in resources utilization but also have a competitive outlook. Effectuation theory is best suited to the environment of developing countries as it enables the entrepreneurs to undertake affordable losses and in the face of uncertainty, create strategic partnerships and use the contingencies to their benefit. In order to achieve this end, the governments in developing countries can play a role of insurer and confidence booster for those entrepreneurs that can create value to the indigenous resources and create employment and competitiveness.
\end{abstract}

(C) 2021 The authors. Published by SPCRD Global Publishing. This is an open access article under the Creative Commons Attribution-

NonCommercial 4.0

Corresponding author's email address: mmali@numl.edu.pk

\section{Introduction}

With current state of globalization it is the interest of every developing nation to maximize entrepreneurial activity, achieve self reliance and improve living standards of the masses. But generally these countries are facing problems of imperfect markets and information. This leads to inefficient allocation of resources in domestic labor and financial markets. The general causes of this underdevelopment are: absence of a vibrant official system of enforcing legal contracts and protecting 
property rights; unsteady and unstable monetary mechanism and currency; weak and insufficient infrastructure causing high cost of communication; a vibrant system of banking and insurance; imperfect market information about prices, quantities, and qualities available to consumers and producers; and social norms of long-term business relationships.

Entrepreneurship is a popular concept among scholars of management sciences, business studies, economics, sociology and psychology. Generally an entrepreneur is considered to be a resultsoriented person possessing high degree of sensitivity for recognizing and developing entrepreneurial opportunities. Entrepreneur undertakes moderately risky decisions with cautious use of available resources to design and implement value-added innovations, and contributes towards societal growth and development (Cala, 2015).

According to the GEM's report (2016), 4.3 percent of the adult population in the United States is entrepreneurs whereas, in Uganda, this percentage is as high as 28.1 percent. The report finds that in developed nations the rate of entrepreneurial startups are far lower than those in the developing countries like Thailand, Brazil, Cameroon, and Vietnam. The survey conducted by The Gallup Organization (2007) revealed problems of entrepreneurs faced especially in the developing countries. The survey indicated the following factors of concern for the entrepreneurs: inadequate infrastructure (23\%) inadequate legal regulations (36\% of the sample), high cost of hiring labor (33\% of the sample), deficiency of working force (35\% of the sample), limited purchasing power of the people ( 46 $\%$ of the sample), and lack of financial resources (21\% of the sample). Therefore, in developing countries, in order to be able to successfully create a new value adding endeavor in the society, the individuals need to have strong beliefs in their capabilities for attaining success and controlling cognitions for successfully tackling challenging goals. Therefore, the entrepreneurial success is determined by the elements of effectuation one possesses in order to better predict the attainments in an uncertain future. Generally, the elements of effectuation are: a thinking framework; a set of heuristics; doing the do-able, and; how to get the sellable products and services established (Fuller et al., 2018; Farah \& Ali, 2018). Expert entrepreneurs have learned that entrepreneurial self efficacy enables them to create most interesting ventures in a space in which the future is not only unknown, but unknowable, and yet, entrepreneurs do shape this unpredictable future. They use techniques which minimize the use of prediction and allow them to shape the future (Fritsch \& Wyrwich, 2018).

The theory of effectual reasoning advanced by Sarasvathy (2001) proposes that the decision process employed by entrepreneurs is different from the traditional mechanism. The traditional models are more concerned about causal reasoning for expected return, competitiveness analyses, and making best use of existing knowledge and technology. But on the other hand, effectual reasoning emphasizes affordable loss, building strategic partnerships, and leveraging of contingencies by crafting creative solutions in crises. Therefore, in the perspective or theory of effectuation, this paper tries to address the problem of low level of enterprise creation and entrepreneurial intention in developing countries. The paper is organized as follows: Section 2 presents a brief historical development of entrepreneurial literature; Section 2 discusses the factors and models of theory of effectuation; Section 3 presents the overview of conditions faced by entrepreneurs generally in developing countries, and; the study concludes with suggestions in the light of theory of effectuation in Section 4.

\section{Evolution of Entrepreneurial Literature}

Over the course of history, the scholars have approached the entrepreneurial activity in varying manners. Entrepreneurship viewed as a mental act (Mises, 1949) is the achievement of a particular outcome one perceives to be profitable and fruitful. Furthermore, he elaborates entrepreneurship as 
consequence of mental activity in the form of actually gathering resources for enterprise creation, i.e. transforming intentions into actions. He attributes this act not only to the entrepreneur but also to the venture capitalist. But Becker (1993) asserts the evolutionary perspective to entrepreneurship as it is the economic evolution and transformation of society that triggers the response of creating new and better solutions for resources utilization. At the same time, he hints towards the availability, development and refinement of human capital to make entrepreneurial activity an ongoing process in the society.

Concept of entrepreneurship developed especially during and after the industrial revolution in the West. According to Cantillon's theory (1755), the entrepreneur is an agent facing risk to create balance between supply and demand (Li, 2008). But another neo classical scholar Jean Say (1855) views entrepreneur as a manager responsible for production and innovation resulting in value addition. Work of neo classic scholars was furthered in the contribution of Alfred Marshall (1875) who viewed entrepreneurial activity to be an innovative process aimed at continuously minimizing costs.

Schultz (1975) argues that disequilibrium in the economy initiates the entrepreneurship as the existing agents perform sub-optimally gives rise to actions leading to reallocation of resources for efficient outcomes. Closely related behavior of entrepreneur was elaborated by Kirzner's (1997). 'Alert' entrepreneurs only have the ability to avert and control disequilibrium in the economy. He did not make strong assumptions like neo-classical economists of market clearing mechanism and perfect information, and recognized the imperfections in which entrepreneurs have to act. Later, in the discovery and opportunity theory of entrepreneurship (equilibrium destruction theory) Schumpeter (1947) elaborates that the ability to innovate rather imitate makes an entrepreneur a leader caring less about profits and more about success of innovation to address societal problems. Therefore, for Schumpeter, entrepreneurial activity is a dynamic process and prevents the economy falling into a static unprogressive order.

Knight (1971) differentiated between risk and uncertainty that businesses and venture capitalists face. He attributed the entrepreneur to vie with the uncertainty and safeguard wealth of shareholders in particular and society in general. Eagly (1995) furthered the work of theorists trying to explain gender differences in undertaking business and commercial activities. In his Biological Theory of Entrepreneurship, he mentioned cultural and biological differences between men and women in entrepreneurial process. This was later refined in the researches of psychologists finding significant gender based differences in risk-taking abilities. Researchers like Powell and Ansic (1997) found that women prefer lower level of financial lower risks than men.

The Social Enterprise School Entrepreneurship seeks market based solutions to social problems either by crafting solutions with the help of charitable contributions or/and public sector subsidies. This is closely linked with sociological theories of entrepreneurship having societal ownership requiring societal action for their performance and survival. These enterprises need team formation based on homophily in the context of opportunity structure i.e. community education, health, protection etc. (Ruef 2001). In this context, the strategic partnerships have emerged to be a success factor for risky entrepreneurial startups in the face of uncertainty while friendships keep teams held together and enhance ability to take on risk especially in difficult times (Francis \& Sandberg, 2000).

In the modern theories of entrepreneurship, the overlooked factor of population and households in neo classical theories is taken care of. Modern theories are somewhat resembling the 'open-set' approach of mathematics that adopts and absorbs viable solutions regardless of the origin to attain 
solutions to the problems. This is particularly addressed in management theories of entrepreneurship facilitating resource re-combinations. Entrepreneurial behavior is tailored in management design of the firm (Eisenhardt \& Martin, 200o). This has lead to departure of management practices from highly administrative to highly entrepreneurial. This redefines the role of 'promoter' as being entrepreneurial while that of a 'trustee' as administrative (Stevenson \& Jarillo, 1986; 1990). Therefore, promoters in the modern organization intend to pursue and exploit opportunities and trustee tries to efficiently use the resources. Stevenson described entrepreneurial management in six dimensions: strategic orientation, commitment to opportunity, commitment to resources, control of resources, management structure and reward philosophy (Fritsch \& Wyrwich, 2018; Brown et al., 2001).

\section{Effectuation: Underpinning Factors and Models}

Efficacy is personal ability to achieve something that can be challenging and difficult to accomplish. Theory of self-efficacy postulates that people undertake those tasks for which they have abilities to succeed, and avoid those that appear to be too challenging to be successful (Fuller et al., 2018). People with strong self-efficacy can take on challenging tasks instead of avoiding them. Such individuals remain strongly committed to the challenging goals and try to take control of threatening situations. According to Bandura (2004), self-efficacy has four dimensions: mastery experience in the form of attaining previous success similar to the new situation; vicarious experience attained through learning by observing others; verbal persuasion by other, and; somatic and emotional states that are caused by the thinking of becoming willing to undertake the challenging task. In this perspective, Sarasvathy (2001) defined effectuation as processes that enable an individual to consider a set of resources as fixed and concentrate on choice between different plausible effects created with available set of means. The basic logic of employing effectuation processes is to control the future instead of trying to predict it. Sarasvathy (2001) differentiated effectuation from the process of causation. Causal processes consider a specific effect as certain and concentrate on making a selection between resources to generate that effect. Causation is used to predict the future that one can possibly control with certain degree of certainty.

According to Bandura (1986) individuals are differentiated on three dimensions of self-efficacy: magnitude in terms of assessing task difficulty; strength of confidence at numerous performance levels, and; generality in integrating magnitude and strength for task accomplishment. The researchers have described self-efficacy on the basis of traits and abilities. The traits based generalization of is termed as general self-efficacy (GSE) which is a self-belief in personal proficiency to attain necessary level of performance to deal with achievement situations (Chen, Gully \& Eden, 2001). In this background the entrepreneurial self-efficacy (ESE) is task specific leading to the venture creation process which is correlated with entrepreneurial intentions (Noble, Jung, \& Ehrlich, 1999). ESE is generally set to address issues of managing innovation, marketing, and financing.

Effectuation is distinguished from the theory of rational choice. Effectuation sets in where the arena of rational choice based on predictability, pre-existent goals, and an independent environment is not sufficient for the decision maker. Most of the start-up entrepreneurs face this situation while trying to overcome the barriers created by rational predictions of different business models (Fuller et al., 2018). But at the same time, effectuation does not replace rationality, instead exists parallel to it.

Effectuation is in fact a rational process of thinking but differentiated from the conventional rational models on the basis of clarity with which goals are pre-defined. Theory of effectuation creates an alternative process helpful for rational decision makers in arriving at choices based on rationality when conditions are uncertain. Scholars like Mauer and Sarasvathy (2010) and Mauer et al. (2010) 
assert that it becomes relatively faster and cheap to create new organizations when entrepreneurs use effectual reasoning especially during the efforts to create new markets for their products and services. Effectuation is process that is initiated by a decision maker who creates a systematic environment that is based on learnable principles having practical implications (Farah \& Ali, 2018). It can be mixed with a randomly driven process because of elements of chance and contingency, but effectuation formulates a method to take advantage of contingency and chance elements to create innovative and original outcomes.

Effectuation is a theory of constrained creativity where entrepreneur is faced with resources constraints out of which best solutions in the face of state uncertainty, effect uncertainty and response uncertainty have to be created. Although the relationship between resources and their outcome is uncertain but it is where the entrepreneurs creates the opportunities and utilize best possible resources mix. Effectuation is different from resource-based view of decision making to use the available valuable resources to create value. Instead, effectuation looks at resources set in a manner to acquire abilities to add value in resources.

The nature of the project and intention of the promoters can make way to effectuation for large projects as well. It addresses the need of 'intrapreneurship' by crating project that has predictive outcomes coupled with effectual procedures to initiate newness even within processes of production. This logic can be extended to the dilemma of perpetual underdevelopment of some counties facing vicious circle of poverty and industrial backwardness (Fritsch \& Wyrwich, 2018). Therefore, effectuation is a broader concept ranging beyond the arena of entrepreneurship that creates environment for action based decision making.

Effectuation cannot be considered as an independent theory rather it integrates concepts of different established theories in economics and management, but yet has its own differentiated outlook. It draws its focus from Schumpeter's innovation intention, builds on first-mover advantage and consumer preferences formation, and takes form of Marchian exploration-exploitation argument for a startup entrepreneur. De Noble et al. (1999) found that innovative business environment and entrepreneurial intention are positively affected by entrepreneurial perception regarding management of risk and uncertainty, innovation, product improvement. Perceptions about locating and acquiring appropriate resources, maintaining professional networks are also important to shape entrepreneurial intention.

Internationalization focuses venture creating process but in literature its connection with venture creation did not gain much attention (Zahra \& George, 2002; Zahra et al., 2005). The same appears to be a problem for entrepreneurs intending to invest in foreign markets having relatively higher degree of uncertainty than local markets (Aharoni, 1966). International new venture (INV) theory terms internalization to be insufficient to allow entrepreneur to develop comparative advantage from it efficient use of resources. In this perspective, theory of effectuation explains to know process of decision making in the face of uncertainty by having strategic partnerships and overcoming challenges (Sarasvathy et al., 2014).

In order to understand whether there exists differences in terms of gender to have management capacities for venture creation, numerous empirical studies are conducted. At the same time some studies have found that in countries with lower and middle level of development, there is a significant impact of culture and social norms on entrepreneurial orientation making it to be a differentiating factor in different tiers of society and entrepreneurship (Minniti \& Bygrave, 2003). Similarly, Aldrich and Waldinger (1990) found that in addition to personal characteristics, the sub-cultural dimensions 
based on ethnicity that connect different ethnic groups in a society are also important for effectual decision making.

In the recent past, the arena of business management has gone through a number of revolutions and paradigm shifts. Effectuation inquires to replace prediction with the logic of control within the framework of rational choice. It also represents a non-teleological approach to create firms and markets by entrepreneurs. It is matter of time and research that will prove theory of effectuation to be an effective tool to search for business problems and resources utilization.

\section{Conditions for Entrepreneurial Startups in Developing Countries}

Porter (2003) bases sources of competitive advantage to describe the level of development of a country. A developing country is that which is at either factor or efficiency-driven stages of taking advantage of low-cost labour, natural resources, and producing standard products and services (Xavier et al., 2012). The production is of commodities with simple designs having limited roles in the value chain due to dependence on imported technology and foreign direct investment. The accumulation of wealth and infrastructure improvements along with capacity for research enables them to move to 'efficiency-driven stage' of development. Therefore, the level and nature of entrepreneurship between developed and developing countries are different due to economic, statistical and legal structures and the quality of information. This difference can the reason of creation of almost seven more new firms per working-age population in developed countries than developing countries.

The eclectic approach to entrepreneurship suggests that entrepreneurial firm creation is based on opportunities and personal characteristics. The individual's risk-reward intention formulate decision pattern for self-employment versus wage employment in institutional setting created and shaped by macroeconomic conditions and government regulations specific to different societies. Public policies especially in developing countries are responsible to pace the process of firm creation especially in terms of basic infrastructures (Carbonell, 2005). These countries have faced difficulties in creating a sustainable long-term industrial policy especially due to political instability (Alcorta \& Peres, 1998).

The weakness of science and technology institutions in developing countries has made it difficult to establish a sound base of technology or knowledge based firms. There is a weak link between firms and academia which can suffice the deficiency of having research and development at firm level. The research being done in academic institutions does not reflect the needs of market demand, nor there exist proper protection of patents (Alcorta \& Peres, 1998). This is one of the reasons that the firms created in developing countries are generally not high-growth businesses (Kantis et al., 2005).

In developing countries, the industrial structure is less diversified as well as fragmented, less dense and based on low level of technological sophistication. Moreover, the production is more in natural resource-intensive goods that also results in localized structure of firms clusters. The lack of diversity limits the business opportunities for knowledge based firms that are source of specialization and differentiation. The lower density of firms causes limiting the benefits of agglomeration and knowledge spillovers. The inefficient economic structure cause high cost of entry and exit for firms that bear the risk of newness in the market. The less conducive industrial structure also makes it difficult to reallocate resources to new activities causing low number of innovation based entry in industry. Kantis et al. (2005) attributes experience, skills and professional networks as a pre-condition for entrepreneurial actions. But industrial structure in developing countries does not support conditioning of entrepreneurial actions. 
Developing countries have low incomes (aggregate and individual) that influence the market conditions of demand and supply causing low level of market mechanism to drive benefits for new ways of using available resources. This is reflected in low supply of entrepreneurs and availability of formal and dynamic firms. The social environment of family, education system and work experience constrain the creation of new projects in the fear of losing existing sources of income in the face of future uncertainty. Therefore, the new startups in developing countries are small and medium enterprises absorbing most of the skilled labor and promoting innovations (Gray, 2006; Griffin \& Ebert, 2006). This sector contributes more than seventy-five percent of gross domestic products in most of the Asian countries (Asian Productivity Organization, 2011). This sector in developing countries is more labor intensive (Task Force for SME Sector Development Programme, 2002) managed mostly by owner and/or family making the role of entrepreneur important for its survival (Dassanayake, 2011; Priyanath, 2006). Therefore, the developing countries are, in general, facing problems of inadequate infrastructure, legal complexities, high cost of hiring labor, deficient working force, limited purchasing power of the people with limited market development, and lack of financial resources.

\section{Best Practices in Developing Countries}

From the previous section it can be understood that entrepreneurs in developing counties face in general the problems of non-conducive external business environment factors (Storey, 1994); complex business registration and taxation systems (Benzing, et al. 2009); scarcity of finance, technological support and logistics (Bruton \& Rubanik, 2002); and lack of managerial skills and financial advise (Watson, 2003; Young \& Welch, 1993). In order to overcome the business problems, the entrepreneurial effectuation can serve as a mean to not just help new startup firms but also enable the existing firms to develop competitiveness. As most of the developing countries are still, in one way or the other, a manifestation of centrally controlled polities, the role of governments cannot be overlooked in enhancing entrepreneurial effectuation. At the same time, the study does not defend nor promotes the role of government in the market mechanism. The recessive nature of private sector tied up in colonial legacy of governance in most of the developing counties, has made it difficult for the entrepreneurial effectuation to take roots and develop business legacies over successive generations.

According to Bandura (1986) individuals are differentiated on three dimensions of self efficacy: magnitude in terms of assessing task difficulty; strength in terms of confidence at different performance levels, and; generality in terms of integrating magnitude and strength for task accomplishment. Therefore, the possible solutions by government or private sector for overcoming entrepreneurial business startups are knitted around these concepts. When put to empirical testing, researchers measure effectuation in terms of: developing product and market opportunities, building an innovative environment, initiating investor relationships, define core purpose of the project, preparation to cope with unexpected challenges, and developing critical human resource.

Developing countries face the problem of demonstration externalities that has bearing on society's perceptions about entrepreneurship. Generally in developing countries entrepreneurship is viewed as an unattractive occupational choice compared to other options as it always involves more risk that wage employment. Similarly, social capital building is a slow process requiring continuous efforts and continuity of supportive public policies. Knowledge generation and information management is an expensive activity that private sector can not undertake in developing countries. Similarly, the network externalities in developing countries due to limited information and access to international markets limit the growth of the local entrepreneurial initiatives.

In general when effectuation is put to practice for entrepreneurship, the fundamentals appear in 
a sequential order starting with clarification and elaboration, followed by awareness, then inculcation, then aspiration, and finally implementation. Therefore, the possible solutions by government or private sector for overcoming entrepreneurial business startups are knitted around these concepts. Therefore, to develop entrepreneurial efficacy of public sector is to focus on enhancing opportunities of Public Sector Entrepreneurship and create enabling ecosystem that can, in turn, support development of private sector entrepreneurship. Similarly, entrepreneurial efficacy should focus on development of such firms by the private sector that has potential to become large corporations.

\subsection{Public Sector Entrepreneurship in developing countries and theory of Effectuation}

- During twentieth century, outbreak of two world wars, depression in many countries and social evils of Industrial Revolution of earlier times compelled state governments to participate in planning and developing industrial structure.

- Public/private nonprofit organizations are always in the market for low-cost, high impact staff fringe benefits but rent seeking behavior has to be taken care of by limiting entrepreneurial activity to: (a) community development; (b) organizational development; (c) workforce development; (d) education development; (e) business development; and, (f) environmental development.

- Collaborates with citizens groups to foster the mutual expansion, utilization and development of resources.

- This will enhance abilities of the communities in terms of learning skills, prototyping, environment protection and community development.

- Motivate to create something of value for community

- Attach civil awards for successful public sector entrepreneurs

\subsection{Private Sector Entrepreneurship in developing countries and theory of Effectuation:}

- Freedom is the guidance, Trust is the virtue.

- Every day, there are many startups are built, but at the same time, many fail. This failure is usually a result of lack of funding or an incompetent management team, therefore, needs some social insurance network for survival.

- Not every academic genius can make a great business man. Academic intelligence can surely help to analyze and build a plausible business model; however, it is the practical and social intelligence that glues the rest together.

- Success in funding and great management: without funding, there won't be any progress, without great management; there won't be talented staff hires who eventually becomes part of a great team.

- Create the possibilities by allocating resources for promoting culture of innovation and creativity in entrepreneurial incubators with the help of Higher Education Commission (HEC) and universities.

- Educate the public regarding benefits linked with innovations and newness, and enable information dissemination to create conducive environment to accept risks in the face of uncertainty

- Enact mechanism to 'Listen to the Entrepreneur'

- Map the Entrepreneurial Eco-system as per the needs of the region (community, resources, labor skills, communication etc.)

- Support fast-growing firms and their needs to access the resources and clients (community funding and private management) 
- Enact framework for Urban-Fringe Development by ensuring provision of services like: water, sewer, housing, roads \& transit, city education, health, parks, protection of wildlife and habitats, fire and other services.

\section{Conclusion}

Developing counties are faced with the problems of non-conducive external business environment, complex business registration and taxation systems, scarcity of finance, technological support and logistics, and lack of managerial skills and financial advice. Theory of effectuation is about doing something do-able that adds to the value to the organization. The lack of social capital in terms of trained labor force and infrastructure makes the contribution of public sector entrepreneurship to create enabling environment that may supplement the private sector entrepreneurship. The theory of effectuation enables the public sector entrepreneurs to create value to social capital that then leads to the private sector actions for creating enterprises having potential to grow from small to large corporations.

\section{References}

Acs, Z. J., Desai, S., \& Klapper, L. F. (2008). What does "entrepreneurship" data really show? Small Business Economics, 31(3), 265-281.

Aharoni, Y. (1966). The foreign investment decision process. Boston, MA: Harvard Business International Marketing, Vol. 15 No.1, pp. 1-29.

Alcorta, L., \& Peres, W. (1998). Innovation Systems and Technological Specialization in Latin America and the Caribbean. Research Policy, 26, 857-81.

Asian Productivity Organization (APO). (2011). APO Productivity Data Book. Asian Productivity Organization. Japan: Keio University Press Incorporation.

Bandura, A. (1986). Social Foundations of Thought and Actions: A Social Cognitive Theory. Englewood Cliffs, NJ: Prentice-Hall.

Bandura, A. (2005). Guide for constructing self-efficacy scales. In A. Bandura, Self-efficacy belief of adolescents (pp. 307-337). Information Age Publishing.

Bartelsman, E., Haltiwanger, J., \& Scarpetta, S. (2004). Microeconomic Evidence of Creative Destruction in Industrial and Developing Countries. Institute for the Study of Labor, IZA, Discussion Paper no 1374. The World Bank, Policy Research Working Paper $n^{0} 3464$.

Benzing C., Chu, H. M., Kara, O. (2009). Entrepreneurs in Turkey: a factor analysis of motivations, success factors and problems. J Small Business Management 47(1):58-91.

Bruton G. D., Rubanik, Y. (2002). Resources of the firm, Russian high-technology startups and firm growth. J Business Venturing 17(6):553-576.

Calá, Carla Daniela., Carod, Josep-Maria Arauzo. and Antolín, Miguel Manjón. (2015). The Determinants of Entrepreneurship in Developing Countries. Working Paper: 1576 - 3382, DEPARTAMENT D’ECONOMIA - CREIP. Spain.

Carbonell, S. (2005). The entrepreneurial environment in Latin America. In: Acs, Z.; Arenius, P.; Hay, M.; Minniti, M. (2004) Global Entrepreneurship Monitor. Executive Report. Babson College/ London Business School.

DeNoble, A. F., Jung, D. \& Ehrlich, B. (1999). Entrepreneurial Self-Efficacy: The Development of a Measure and Its Relationship to Entrepreneurial Action. Babson College.

European Union. (2012). Small and medium-sized enterprises: A second chance to entrepreneurs. Retrieved March 28, 2012, from Union: http://ec.europa.eu/enterprise/policies/sme/busines s-environment/failure-newbeginning/.

Farah, S. A., \& Ali, H. A. (2018). A Study on perception of business students on the future job 
market: A case study of Umma University. International Journal of Scientific Research and Management, 6(04), 274-281. https://doi.org/10.18535/ijsrm/v6i4.emo6.

Fritsch, M., \& Wyrwich, M. (2018). Regional knowledge, entrepreneurial culture, and innovative start-ups over time and space - an empirical investigation. Small Business and Economics, 2(51), 337-353. doi:10.1007/s11187-018-0016-6.

Fuller, J., Liu, Y., Bajaba, S., Marler, L., \& Pratt, J. (2018). Examining how the personality, selfefficacy, and anticipatory cognitions of potential entrepreneurs shape their entrepreneurial intentions. Personality and Individual Differences. 125, 120-125.

Gray, C. (2006). Absorptive capacity, knowledge management and innovation in entrepreneurial small firms. International Journal of Entrepreneurial Behaviour and Research, 12, 345-36o.

Griffin, T., \& Ebert, R. (2006). Business (8 ed.). New York: Pearson Prentice hall.

Johanson, J. and Vahlne, J.-E. (2009), “The Uppsala internationalization process model revisited: From liability of foreignness to liability of outsidership”, Journal of International Business Studies, Vol. 40, pp. 1411-1431.

Kantis, H., Angelelli, P., \& Moori Koening, V. (2005). Developing Entrepreneurship: Experience in Latin America and Worldwide. Inter-American Development Bank, NW.

Li, J. (2008). The evolution of entrepreneurial intention in transition environment: towad an Entrepreneurial self-efficacy based Model. Retrieved november 7, 2011, from IEEE Xplore:http://ieeexplore.ieee.org/stamp/stamp.jsp?tp=\&arnumber $=4679344$.

Luthans, F., \& Ibrayeva, E. S. (2006). Entrepreneurial self-efficacy in Central Asian transition economies: Quantitative and qualitative analysis. Journal of International Business Studies, 37 (1), 92-111.

Oviatt, B. and McDougall, P. (1994), “Toward a theory of international new ventures”, Journal of International Business Studies, Vol. 25 No. 1, pp. 45-64.

Porter, M. (2003). Building the Microeconomic Foundations of Prosperity: Findings from the Microeconomic Competitiveness Index. In World Economic Forum (2003) The Global Competitiveness Report 2002-2003 (pp. 23-46) Oxford: Oxford University Press.

Priyanath, H. M. (2006). Managerial deficiencies in the small and medium enterprises in Sri Lanka: An empirical evidance of SMEs in rathnapura district. Sabaragamuwa University Journal, 6 (1), 93-105.

Read, Stuart. \& Sarasvathy, S. (2005) Knowing what to do and doing what you know: Effectuation as a form of entrepreneurial expertise.

Sarasvathy, S., Kumar, K., York J.G. and Bhagavatula, S. (2014), "An effectual approach to international entrepreneurship: Overlaps, challenges, and provocative possibilities", Entrepreneurship Theory \& Practice, Vol. 38, No. 1, pp. 71-93.

Sarasvathy, S.D. (2001), "Causation and effectuation: Towards a theoretical shift from economic inevitability to entrepreneurial contingency”, Academy of Management Review, Vol. 26, pp. 243-288.

Stiglitz, J. (2010). Freefall: American Free Markets and the Sinking of the World Economy. New York, NY: W.W. Norton \& Company, Inc.

Storey D (1994) Understanding the small business sector. Routledge, London.

Task Force for SME Sector Development Programme. (2002). National strategy for SME sector Development in Sri Lanka. Colombo: Ministry of Enterprise Development and Investment Promotion.

The Gallup Organization (2007) Survey of the observatory of European SMEs. The Gallup Organization, Hungary.

Watson J (2003) The potential impact of accessing advice on SME failure rates. In: Proceedings of the 16th annual conference of small enterprise association of Australia and New Zealand, 
University of Ballarat, Ballarat, 28 Sept-1 Oct 2003.

Xavier, S.R, Kelley, D.J., Kew, J., Herrington, M.D., \& Vorderwülbecke, A. (2012). The Global Entrepreneurship Monitor. 2012 Global Report.

Young EC, Welch HP (1993) Major elements in entrepreneurial development in central Mexico. J Small Business Management 31(4):80-85.

Zahra, S.A. and George, G. (2002), "Absorptive capacity: A review, reconceptualization and extension”, Academy of Management Review, Vol. 27 No. 2, pp. 185-203.

Zahra, S.A., Korri, J.S. and Yu, J. (2005), "Cognition and international entrepreneurship: implications for research on international opportunity recognition and exploitation", International Business Review, Vol. 14 No. 2, pp. 129-146. 
Table 1: Measures of Entrepreneurship

\section{Measures of entrepreneurship}

\begin{tabular}{|c|c|c|}
\hline Measure & Definition & Source \\
\hline $\begin{array}{l}\text { Nascent } \\
\text { entrepreneurship }\end{array}$ & $\begin{array}{l}\text { Percentage of adult population that have taken action to } \\
\text { create a new business in the past year but have not paid any } \\
\text { salaries for more than } 3 \text { months. }\end{array}$ & \multirow{5}{*}{ GEM } \\
\hline New business start-ups & $\begin{array}{l}\text { Percentage of adult population that own or manage a new } \\
\text { business from } 3 \text { to } 42 \text { months old. }\end{array}$ & \\
\hline $\begin{array}{l}\text { Total entrepreneurial } \\
\text { activity (TEA) }\end{array}$ & $\begin{array}{l}\text { Nascent entrepreneurship + New business start-ups. Also } \\
\text { called "Early-stage Entrepreneurial Activity Index" (EA). }\end{array}$ & \\
\hline $\begin{array}{l}\text { Opportunity-based } \\
\text { entrepreneurs }\end{array}$ & $\begin{array}{l}\text { Entrepreneurs who have taken action to create a new venture } \\
\text { in pursuit of perceived business opportunities. }\end{array}$ & \\
\hline $\begin{array}{l}\text { Necessity-based } \\
\text { entrepreneurs }\end{array}$ & $\begin{array}{l}\text { Entrepreneurs who have taken action to create a new venture } \\
\text { because of the lack of better employment alternatives }\end{array}$ & \\
\hline Entry density & $\begin{array}{l}\text { Number of newly registered limited-liability firms per } 1000 \\
\text { working age population. }\end{array}$ & \multirow{3}{*}{$\begin{array}{l}\text { WB Group } \\
\text { Entrepreneurs } \\
\text { hip Survey } \\
\text { (WBGES) }\end{array}$} \\
\hline Entry rate & $\begin{array}{l}\text { New firms over the total number of lagged registered } \\
\text { businesses. }\end{array}$ & \\
\hline Business density & $\begin{array}{l}\text { Number of existing registered companies with limited liability } \\
\text { per } 1,000 \text { working age population. }\end{array}$ & \\
\hline Entry rate & $\begin{array}{l}\text { Number of new firms as a ratio of the total number of } \\
\text { incumbent and entrant firms in a given year. }\end{array}$ & $\begin{array}{c}\text { Distributed } \\
\text { micro-data } \\
\text { analysis } \\
\text { (Bartelsman e } \\
\text { al. 2004) }\end{array}$ \\
\hline $\begin{array}{l}\text { Complex } \\
\text { Entrepreneurship } \\
\text { Context index }\end{array}$ & $\begin{array}{l}\text { Based on } 26 \text { variables that measure entrepreneurial activity, } \\
\text { strategy and attitudes for } 54 \text { countries across 2003-2006. }\end{array}$ & $\begin{array}{c}\text { Acs et al. } \\
(2008)\end{array}$ \\
\hline
\end{tabular}

Source: Cala, Carod and Antolin (2015) 
Table 1: Startup Rates in Selected Countries

\begin{tabular}{|c|c|c|c|c|c|c|c|c|c|c|c|}
\hline Economy & $\begin{array}{c}\text { Number of } \\
\text { new } \\
\text { limited } \\
\text { liability } \\
\text { companies }\end{array}$ & $\begin{array}{c}\text { New } \\
\text { Entry } \\
\text { Rate }\end{array}$ & Economy & $\begin{array}{c}\text { Number } \\
\text { of new } \\
\text { limited } \\
\text { liability } \\
\text { companies }\end{array}$ & $\begin{array}{c}\text { New } \\
\text { Entry } \\
\text { Rate }\end{array}$ & Economy & $\begin{array}{c}\text { Number of } \\
\text { new } \\
\text { limited } \\
\text { liability } \\
\text { companies }\end{array}$ & $\begin{array}{c}\text { New } \\
\text { Entry } \\
\text { rate }\end{array}$ & Economy & $\begin{array}{c}\text { Number of } \\
\text { new } \\
\text { limited } \\
\text { liability } \\
\text { companies }\end{array}$ & $\begin{array}{c}\text { New } \\
\text { Entry } \\
\text { rate }\end{array}$ \\
\hline $\begin{array}{c}\text { Pakistan } \\
(2002)\end{array}$ & 1,268 & 0.01 & Philippines & 16,143 & 0.27 & Albania & 2,114 & 1.11 & Romania & 56,381 & 4.07 \\
\hline $\begin{array}{c}\text { Pakistan } \\
(2003)\end{array}$ & 1,601 & 0.02 & Indonesia & 47,549 & 0.29 & $\begin{array}{c}\text { Dominican } \\
\text { Republic }\end{array}$ & 8,061 & 1.20 & $\begin{array}{c}\text { Russian } \\
\text { Federation }\end{array}$ & 427,388 & 4.20 \\
\hline $\begin{array}{c}\text { Pakistan } \\
(2004)\end{array}$ & 2,367 & 0.03 & Argentina & 11,672 & 0.43 & Canada & 30,904 & 1.28 & Denmark & 15,806 & $4 \cdot 36$ \\
\hline $\begin{array}{c}\text { Pakistan } \\
(2005)\end{array}$ & 2,719 & 0.03 & Sri Lanka & 6,110 & 0.44 & Germany & 68,526 & 1.29 & Maldives & 904 & $4 \cdot 39$ \\
\hline $\begin{array}{c}\text { Pakistan } \\
(2005)\end{array}$ & 3,109 & 0.03 & South Sudan & 3,148 & 0.51 & Armenia & 3,139 & 1.52 & Portugal & 31,860 & 4.62 \\
\hline Ethiopia & 1,327 & 0.03 & El Salvador & 2,104 & 0.52 & Tunisia & 11,307 & 1.52 & Croatia & 13,073 & 4.63 \\
\hline $\begin{array}{c}\text { Pakistan } \\
(2008)\end{array}$ & 3,593 & 0.03 & Bolivia & 3,734 & 0.57 & Morocco & 34,658 & 1.54 & $\begin{array}{c}\text { Netherland } \\
\text { s }\end{array}$ & 58,900 & $5 \cdot 34$ \\
\hline $\begin{array}{c}\text { Pakistan } \\
(2010)\end{array}$ & 4,086 & 0.04 & Algeria & 15,574 & 0.58 & Qatar & 3,288 & 1.70 & Sweden & 39,263 & 6.41 \\
\hline $\begin{array}{l}\text { Pakistan } \\
(2011) \\
\end{array}$ & 4,162 & 0.04 & Algeria & 11,769 & 0.59 & Oman & 3,165 & 1.74 & $\begin{array}{l}\text { South } \\
\text { Africa }\end{array}$ & 217,440 & 6.53 \\
\hline $\begin{array}{c}\text { Pakistan } \\
(2012) \\
\end{array}$ & 4,553 & 0.05 & Nepal & 11,904 & 0.69 & Taiwan & 30,876 & 1.85 & Estonia & 6,312 & 6.91 \\
\hline $\begin{array}{l}\text { Pakistan } \\
(2013) \\
\end{array}$ & 4,830 & 0.04 & Austria & 4,181 & 0.73 & Colombia & 62,993 & 2.00 & Norway & 25,888 & 7.72 \\
\hline $\begin{array}{c}\text { Pakistan } \\
(2014)\end{array}$ & 3,917 & 0.04 & Nigeria & 71,941 & 0.76 & Belgium & 14,897 & 2.05 & Chile & 98,406 & 8.03 \\
\hline $\begin{array}{c}\text { Pakistan } \\
(2015)\end{array}$ & 4,289 & 0.04 & Greece & 5,761 & 0.77 & France & 94,927 & 2.26 & Bulgaria & 42,613 & 8.86 \\
\hline $\begin{array}{c}\text { Syrian Arab } \\
\text { Republic }\end{array}$ & 500 & 0.04 & Uzbekistan & 14,487 & 0.77 & Korea, Rep. & 84,676 & 2.30 & Iceland & 2,059 & 9.48 \\
\hline $\begin{array}{c}\text { Congo, } \\
\text { Dem. Rep. }\end{array}$ & 1,765 & 0.05 & $\begin{array}{c}\text { Bosnia and } \\
\text { Herzegovina }\end{array}$ & 2,192 & 0.83 & Italy & 91,853 & 2.32 & Singapore & 38,306 & 9.51 \\
\hline $\begin{array}{c}\text { Pakistan } \\
(2009)\end{array}$ & 5,171 & 0.06 & Kenya & 17,896 & 0.84 & Malaysia & 49,203 & 2.37 & $\begin{array}{c}\text { United } \\
\text { Kingdom }\end{array}$ & 479,545 & 11.62 \\
\hline Bhutan & 30 & 0.06 & Thailand & 40,900 & 0.85 & Switzerland & $12,86 \mathrm{o}$ & 2.42 & $\begin{array}{l}\text { Cook } \\
\text { Islands }\end{array}$ & 88 & 11.64 \\
\hline Malawi & 619 & 0.08 & Ghana & 13,154 & 0.90 & Spain & 84,399 & 2.71 & Botswana & 16,850 & 13.11 \\
\hline Bangladesh & 9,193 & 0.09 & Mexico & 76,447 & 0.94 & Brazil & 73,614 & 2.88 & Cyprus & 11,169 & 13.70 \\
\hline India & 98,029 & 0.12 & Azerbaijan & 6,803 & 0.99 & Uruguay & 6,473 & 2.98 & Australia & 231,920 & 14.91 \\
\hline Iraq & 2,309 & 0.13 & Belarus & 7,019 & 1.05 & Belize & 655 & 3.08 & Estonia & 13,867 & 16.05 \\
\hline $\begin{array}{c}\text { Burkina } \\
\text { Faso } \\
\end{array}$ & 1,268 & 0.15 & $\begin{array}{c}\text { United Arab } \\
\text { Emirates }\end{array}$ & 7,700 & 1.06 & Dominica & 158 & $3 \cdot 30$ & $\begin{array}{c}\text { New } \\
\text { Zealand }\end{array}$ & 49,156 & 16.63 \\
\hline $\begin{array}{c}\text { Afghanista } \\
n\end{array}$ & 2,289 & 0.15 & Costa Rica & 3,778 & 1.10 & $\begin{array}{c}\text { Czech } \\
\text { Republic }\end{array}$ & 24,366 & 3.42 & Hong Kong & 167,280 & 31.30 \\
\hline Japan & 11,886 & 0.15 & Turkey & 53,383 & 1.10 & Finland & 11,961 & 3.43 & $\begin{array}{c}\text { Virgin } \\
\text { Islands, } \\
\text { British }\end{array}$ & 77,022 & $\begin{array}{c}4388 . \\
97\end{array}$ \\
\hline
\end{tabular}


Figure 1

The Effectual Process

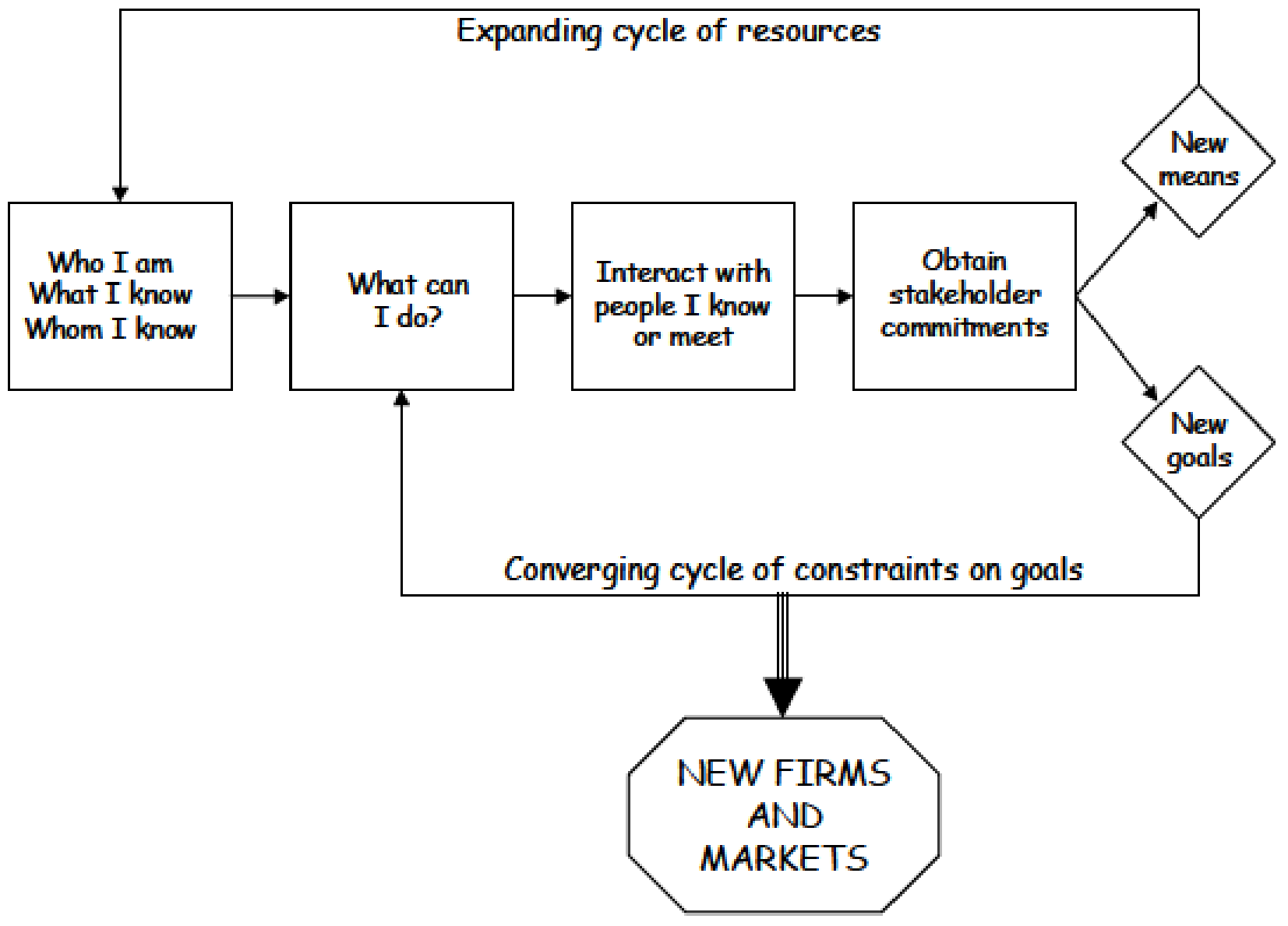

Source: Read and Savarsvathy (2005) 